\title{
Purification and molecular mass determination of a lipid transfer protein exuded from Vigna unguiculata seeds
}

\author{
Mariângela S. S. Diz, André O. Carvalho and Valdirene M. Gomes*1
}

Laboratório de Fisiologia e Bioquímica de Microrganismos, Centro de Biociências e Biotecnologia, Universidade Estadual do Norte Fluminense, Av. Alberto Lamego 2.000, Parque Califórnia, Campos dos Goytacazes, RJ, Brasil. *Corresponding author: valmg@uenf.br Received: 10/11/2003, Accepted: 27/11/2003.

Plants exude a variety of substances through their surface especially of roots and germinating seeds. Some of these released compounds seem to have an inhibitory action against certain pathogens. Lipid transfer proteins (LTPs) are $9 \mathrm{kDa}$ cysteine-rich cationic peptides and are thought to play a role in the protection of plants against microbial infections. The aim of this work was to isolate and determine the molecular mass of a LTP present in the exudates of imbibed cowpea seeds. For exudation induction, 50 seeds were submerged in $50 \mathrm{~mL}$ sterile $100 \mathrm{mmol} . \mathrm{L}^{-1} \mathrm{Na}$-acetate buffer, $\mathrm{pH} 4.5$ and shaken at $30{ }^{\circ} \mathrm{C}$ for $24 \mathrm{~h}$. The resulting exudate was subjected to ammonium sulphate fractionation and the pellet formed between 0 and $70 \%$ saturation was dialysed and recovered by freeze drying. Further purification steps were carried out using chromatographic methods and the molecular mass of the LTP determined. All of these steps were monitored by SDS-Tricine gel electrophoresis and Western blotting using an anti-LTP serum. The purified LTP showed a relative molecular mass of $9 \mathrm{kDa}$.

Key words: Defense proteins, LTP, seed exudates.

Purificação e determinação da massa molecular de uma proteína transportadora de lipídeos exsudada de sementes de Vigna unguiculata: Plantas exsudam uma variedade de substâncias através de sua superfície, especialmente de raízes e sementes germinantes. Algumas dessas substâncias parecem apresentar atividades inibitórias contra determinados patógenos vegetais. Proteínas transportadoras de lipídeos (LTPs) são peptídeos catiônicos básicos de $9 \mathrm{kDa}$, ricos em cisteína e que possuem a função de proteção de plantas contra infecções microbianas. $\mathrm{O}$ objetivo deste trabalho foi o isolamento e a determinação da massa molecular de uma LTP presente em exsudatos de sementes embebidas de feijão-de-corda (Vigna unguiculata). Para indução da exsudação, 50 sementes foram submersas em $50 \mathrm{~mL}$ de tampão acetato de sódio, 100 mmol.L-1. $\mathrm{pH}$ 4,5 e mantidas a $30^{\circ} \mathrm{C}$ sob agitação por $24 \mathrm{~h}$. O exsudato foi submetido à precipitação por sulfato de amônio e o precipitado formado entre 0 e 70 \% de saturação foi dialisado, recuperado por liofilização e submetido a cromatografias para a purificação e determinação da massa molecular da LTP. Todas as etapas foram monitoradas por eletroforese em gel de tricina e por Western blotting, usando-se anticorpo produzido contra LTP isolada de sementes de feijão-de-corda. A proteína transportadora de lipídeo purificada apresentou massa molecular de $9 \mathrm{kDa}$.

Palavras-chave: Exsudatos de sementes, LTP, proteínas de defesa.

Cowpea (Vigna unguiculata) is a legume of West African origin whose seeds are rich in protein and which are widely consumed by poor populations throughout the tropics (Singh and Rachie, 1985). In Brazil cowpea is mostly cultivated in the Northeastern region and is the main protein source for most of the poor population in this region. The plant is considered to have a low level of defense against herbivores and microorganisms in general and this is thought to underlie the very low yields of this legume (Latunde-Dada, 1990).
Nevertheless, several cowpea varieties or cultivars are able to display defences against many viruses, bacteria, fungi and insects (Xavier-Filho, 1993). In recent years, several proteins such as trypsin and papain inhibitors, glucan hydrolases, variant vicilins and antimicrobial peptides have been found in seeds of cowpea and these are frequently linked to plant defense mechanisms (Xavier-Filho et al., 1989; Macedo et al., 1995; Gomes et al., 1996; Gomes et al., 1997; Carvalho et al., 2001). 
Lipid transfer proteins (LTP) facilitate transfer of lipids between membranes in vitro. Up to now they have been found to be localized basically in the plant cell wall and partly in compartments linked to lipid metabolism, such as glyoxysomes. These non-specific lipid transfer proteins (LTPs) have various properties in common: the ability to bind fatty acids and their derivatives, molecular masses of 9 to 10 $\mathrm{kDa}$, high isoelectric points and the presence of eight cysteine residues engaged in four disulfide bridges (Kader, 1996). LTPs have been demonstrated to inhibit several phytopathogens, such as Pseudomonas solanacearum, Clavibacter michiganensis, Fusarium solani, Rhizoctonia solani, Trichoderma viride and Cercospora beticola (Terras et al., 1992; Molina et al., 1993; Kader, 1996; Carvalho et al., 2001). A defense role for these peptides is supported by evidence of their preferential cell wall location in epidermal cells throughout the plant and by the increased expression of their genes in response to pathogens (Kader, 1996).

We have recently shown that cowpea seeds exude several defense-linked proteins such as $\beta-1,3$ glucanases, cystatins, vicilins and lipid transfer proteins (LTPs), from the very first hours of imbibition. These exudates also show an in vitro inhibitory effect on the growth of the fungus Fusarium oxysporum (Gomes VM, personal communication). Some other antimicrobial proteins have also been reported in exudates from Zea mays (Duvick et al., 1992), Mirabilis jalapa (Cammue et al., 1992) and Amaranthus caudatus (Broekaert et al., 1997) seeds.

In this communication we report on the purification and molecular mass determination of a lipid transfer protein exuded from imbibed cowpea seeds. Cowpea (Vigna unguiculata L. Walp.) seeds of the Epace-10 cultivars were supplied by the Centro de Ciências Agrárias, Universidade Federal do Ceará, Fortaleza, Brazil. Polyclonal antibodies against the purified lipid transfer protein (LTP) from cowpea seeds were prepared as described by Carvalho et al. (2001). Protein content was determined as described by Bradford (1976) using BSA as protein standard.

Seed exudates were collected from cowpea using methods similar to those described by Nelson and Hsu (1994). Fifty seeds, with no cracks or other visible deformations were surface sterilized for $5 \mathrm{~min}$ in $25 \mathrm{~mL} 0.5 \%$ sodium hypochloride containing one drop of Tween 20 as a wetting agent and rinsed three times with sterile water. Surface sterilized seeds were imbibed into $50 \mathrm{~mL}$ sterile 1 mol.L $\mathrm{L}^{-1}$ Na-acetate buffer, $\mathrm{pH} 4.5$, and kept at $30^{\circ} \mathrm{C}$ on a rotary shaker. After $24 \mathrm{~h}$, the flask content was filtered, precipitated with
$70 \%$ ammonium sulphate, dialysed against water and liophylized (F/0-70 fraction).

A DEAE-Sepharose column $(1.5 \times 10 \mathrm{~cm})$ equilibrated with 50 mmol. $\mathrm{L}^{-1}$ Tris-HCl, $\mathrm{pH}$ 8.0, was initially employed for separation of basic proteins from the F/0-70 fraction. Elution was initiated with the equilibrium buffer (fraction P1) and bound proteins eluted by 1 mol. $\mathrm{L}^{-1} \mathrm{NaCl}$ in the same buffer (fraction $\mathrm{P} 2$ ). The $\mathrm{P} 1$ fraction was pooled and submitted to Western blotting for LTP characterization. For further purification, the $\mathrm{P} 1$ fraction was subjected to a chromatography on Superdex peptide HR-10/30. The sample was diluted in 0.02 mol. $\mathrm{L}^{-1}$ phosphate buffer, $\mathrm{pH} 6.8$ containing $0.25 \mathrm{~mol} . \mathrm{L}^{-1} \mathrm{NaCl}$ and injected onto the column $(50 \times 5 \mathrm{~mm})$. The chromatography was developed at a flow rate of $0.8 \mathrm{~mL} \cdot \mathrm{min}^{-1}$ with phosphate buffer for $40 \mathrm{~min}$. Proteins were monitored by on-line measurements of the absorbance at $280 \mathrm{~nm}$. SDS-tricine gel electrophoresis was performed according to the method of Schagger and Von Jagow (1987). Gels were fixed and proteins visualized by staining with $0.1 \%$ Coomassie brilliant blue R250 in methanol-water-acetic acid $(1: 8: 1, \mathrm{v} / \mathrm{v} / \mathrm{v})$ or by silver staining (protein silver stain kit, Amersham). Mioglobin (16.95 kDa), Mioglobin I+II (14.4kDa), Mioglobin I+III (10.6 kDa), Mioglobin I ( $8.16 \mathrm{kDa})$ and Mioglobin II (6.2 kDa) were used as molecular weight markers (MW-SDS-17S, Sigma).

Western blotting was performed by transferring proteins to nitrocellulose membranes after polyacrylamide gel electrophoresis, according to the method described by Towbin et al. (1979). The blots were incubated overnight with the primary antiserum against LTP diluted 1:2000 in the blocking buffer $\left(0.1\right.$ mol.L-1 $\mathrm{L}^{-1}$ hosphate buffer, $\mathrm{pH} 7.3$ containing 0.15 mol. $\mathrm{L}^{-1} \mathrm{NaCl}$ and $2 \%$ defatted milk). After incubation the membranes were washed (4 times, 10 min each) with 0.1 mol. $\mathrm{L}^{-1}$ phosphate buffer, $\mathrm{pH} 7.3$ containing 0.15 mol. $\mathrm{L}^{-1}$ $\mathrm{NaCl}$. The blots were incubated with alkaline peroxidaseconjugated goat anti-rabbit secondary antibody (Sigma Immuno Chemicals) (1:2000 in blocking buffer) for $2 \mathrm{~h}$ at room temperature and were washed as above. Blots were developed using a chemiluminescence detection Kit (ECLWestern blotting detection reagents/ RPN 2209) according to the manufacturer's instructions. The chemiluminescence signal was recorded on an X-ray film and photographed.

A lipid transfer protein from exudates obtained from cowpea seeds was purified and characterized using a combination of ammonium sulphate precipitation, ion exchange and gel-filtration chromatography. The 0-70 ammonium sulphate fraction was analyzed for its protein 
profile by tricine gel electrophoresis (figure 1, lane F/0-70). Several proteins with molecular masses from 6 to higher than $16.9 \mathrm{kDa}$ were exuded from imbibed cowpea seeds. The presence of LTP was determined by using a specific antiserum after Western blot transfer (figure 1, lane - W). A DEAESepharose column equilibrated with $50 \mathrm{mM}$ Tris- $\mathrm{HCl}, \mathrm{pH}$ 8.0 , was initially utilized for the separation of basic peptides following ammonium sulphate precipitation. The basic fraction (the non retained P1 peak) represents the minor protein fraction (figure 2). The electrophoretic analysis of $\mathrm{P} 1$ proteins obtained from the anion-exchange chromatography and stained with Coomassie brilliant blue showed the presence of two major sets of bands in SDS-tricine gel after treatment with $\beta$-mercaptoethanol. The first set is comprised of two bands of Mr higher than $16.9 \mathrm{kDa}$ while the second one shows two low Mr proteins with apparent molecular masses between 6.2 and $8.1 \mathrm{kDa}$ (figure 3 - lane P1). The immunoscreening of the fraction with an anti-LTP serum by Western blotting showed a protein with molecular mass of approximately 8-9 $\mathrm{kDa}$ that cross-reacted with the antiserum indicating the presence of a LTP in the basic fraction of the exudate (figure 3 - lane W). In order to further purify the LTP the F/0-70 fraction was also subjected to gel filtration chromatography on Superdex peptide HR-10/30 utilizing the HPLC system. The proteins were separated in six new fractions denominated H1, H2, H3, H4, H5 and H6 (figure 4). Protein patterns from these peaks were analyzed by tricine gel electrophoresis and visualized by silver staining. The results showed the presence of several proteins with molecular masses from 6 to higher than $16.9 \mathrm{kDa}$ distributed in all fractions (figure 5 - lanes $\mathrm{H} 1$ to H6). The $\mathrm{H} 4$ fraction showed the presence of a protein with an approximate $\mathrm{Mr}$ of $9 \mathrm{kDa}$ that positively reacted with the antiserum against LTP (figure 5).

In recent years an increasing number of cysteine-rich antimicrobial peptides have been isolated from plants and particularly from seeds (Broekaert et al., 1997). During germination, seeds release several compounds that may interfere with the development of microorganisms. Some of these compounds have beneficial effects for the germination itself and others are chemical inhibitors, which prevent seed colonisation by predators (Barbour et al., 1991). Terras et al. (1995), for example, showed that radish seeds inhibit fungal growth when these seeds are allowed to germinate in medium supporting growth of a fungal colony, indicating a release of antifungal compounds by these germinating seeds. In this paper we report the isolation and mass determination of a LTP present in exudates from imbibed cowpea seeds (figure
1). The exuded LTP from cowpea was seen to be present in non-retained fraction after anion exchange chromatography and proved to be a basic protein with an apparent molecular mass of $\sim 9 \mathrm{kDa}$ (figures 2 and 3 ). This estimated $\mathrm{Mr}$ for the exuded LTP lies in the range of molecular masses found by several authors for these antimicrobial peptides isolated from other plants (Segura et al., 1993; Cammue et al., 1995; Regente and de La Canal, 1995; Velazhahan et al., 2001).

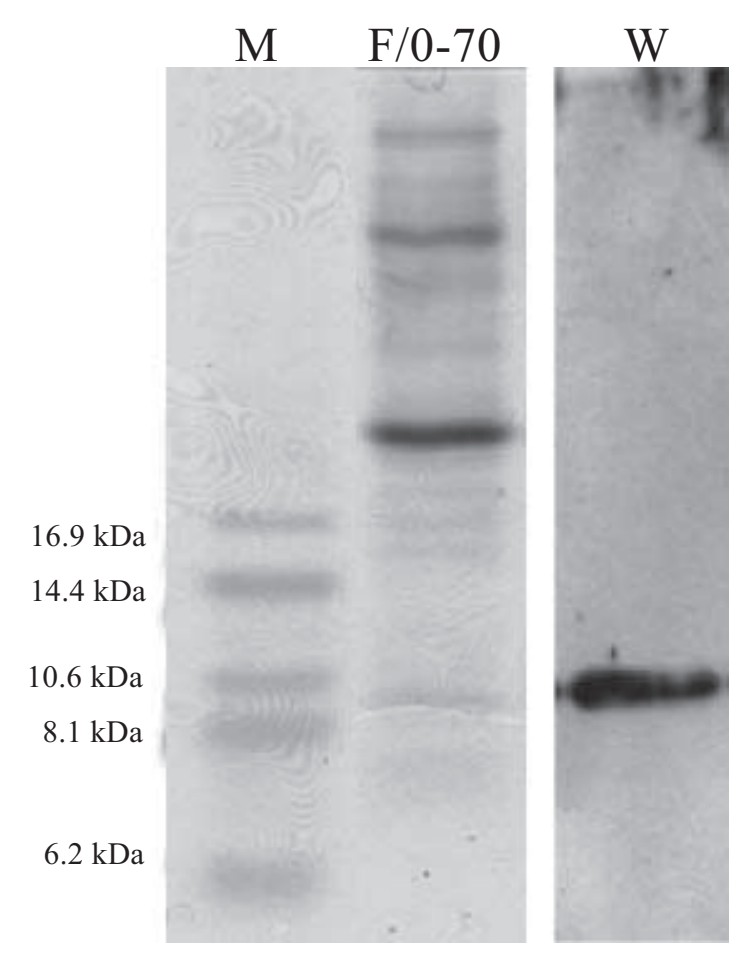

Figure 1. SDS-tricine gel electrophoresis and Western blotting of proteins present in cowpea seeds exudate. F/0-70 Ammonium sulphate fraction obtained from acetate buffer imbibed seed exudates; $\mathrm{W}$ - Western blotting of the F/090 fraction using a specific anti-LTP serum. Numbers in lane (M) refer to molecular mass markers.

The isolation of the exuded LTP from cowpea seeds was performed basically by submitting the P1 fraction (basic fraction from DEAE-Sepharose) to Superdex peptide HR-10/ 30 chromatography in HPLC (figure 4). The H4 fraction showed the presence of a protein which positively reacted against the specific antiserum. The isolated LTP showed a relative molecular mass of $\sim 9 \mathrm{kDa}$ by SDS-tricine gel electrophoresis (figure 5). We have previously demonstrated that other defense proteins such as chitinases, B-1,3glucanases, cystatins and vicilins along with LTP were released during the imbibition of cowpea seeds (Rose et al., submitted for publication). We have also shown that cowpea 


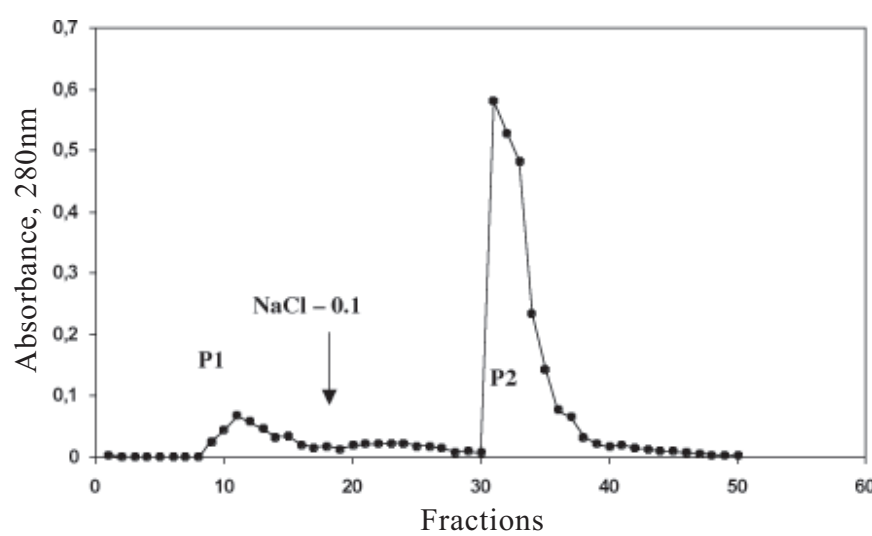

Figure 2. DEAE-Sepharose chromatography of the F/0-70 fraction. The column was previously equilibrated with 50 mmol.L-1 Tris-HCl pH 8.0 buffer and eluted with 1 mol.L${ }^{1} \mathrm{NaCl}$. The flow rate was $50 \mathrm{~mL} \cdot \mathrm{h}^{-1}$ and $1 \mathrm{~mL}$ fractions were collected.

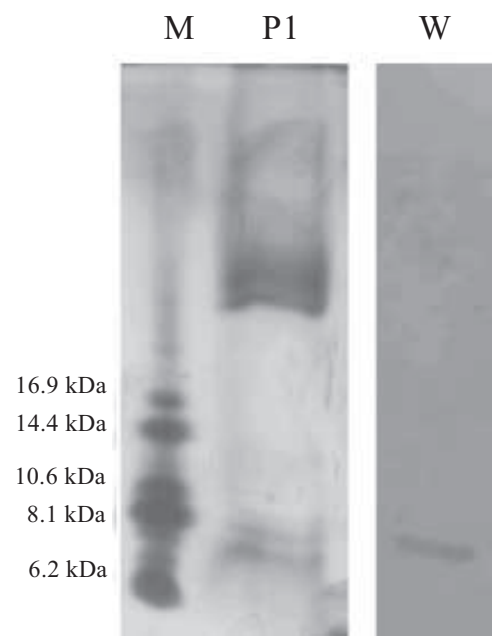

Figure 3. SDS-tricine gel electrophoresis and Western blotting proteins from cowpea seeds exudate. P1 - Peak nonretained (basic fraction) obtained after chromatography on DEAE-Sepharose; $\mathrm{W}$ - Western blotting of the P1 fraction using an specific anti-LTP serum. Numbers in lane (M) refer to molecular mass markers.

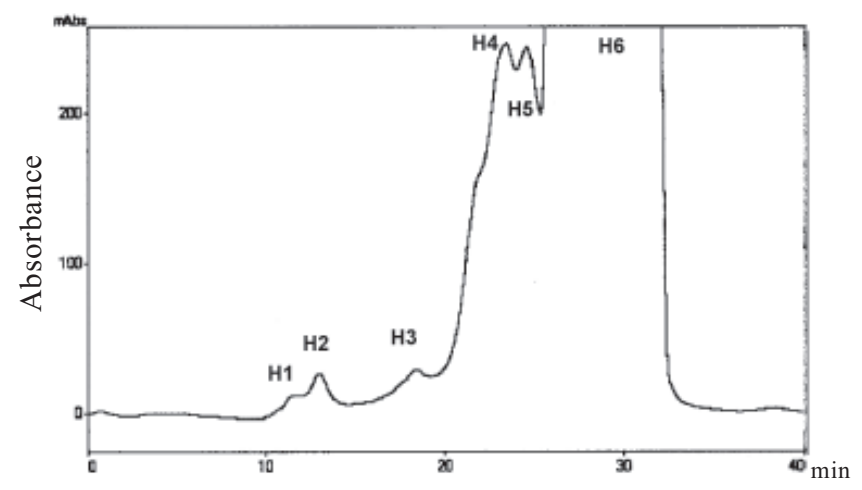

Figure 4. Superdex peptide HR-10/30-HPLC chromatography of the P1 fraction.

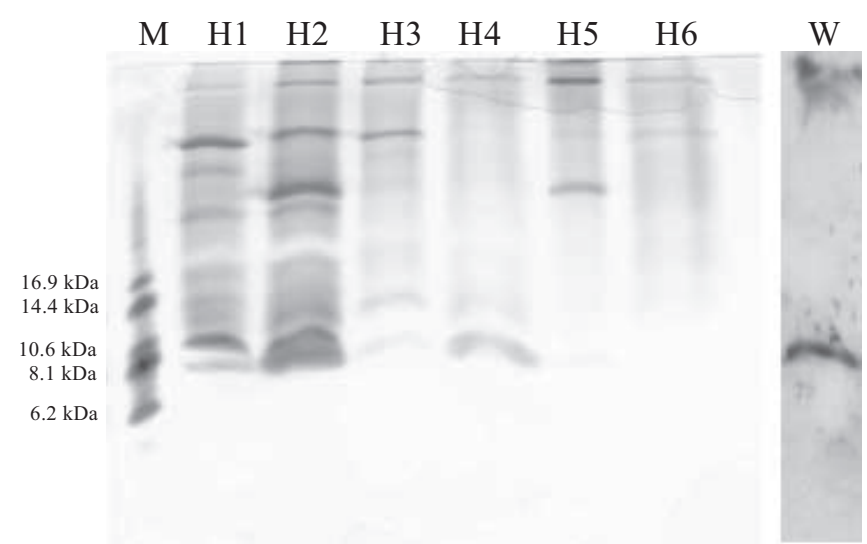

Figure 5. SDS-tricine gel electrophoresis and Western blotting of protein fractions from the Superdex peptide HR-10/30HPLC chromatographic step. H1 to H6 - Protein peaks obtained after chromatography on Superdex peptide HR10/30; W - Western blotting of the H4 fraction using a specific anti- LTP serum. Numbers in lane (M) refer to molecular mass markers.

seeds presented LTP-like peptides located inside organelles, more specifically protein storage vacuoles (Carvalho et al., 2001). In this present work we isolate a LTP protein which is exuded from imbibed cowpea seeds, and that may function in the protection of the germinating seed against microorganisms. Antimicrobial activity of LTPs have already been reported for all tested members of this protein family and the relative antimicrobial activities of different LTPs have some degree of specificity for specific pathogens (Molina et al., 1993; Cammue et al., 1995; Carvalho et al., 2001). Exuded LTP may perform an important physiological role in constitutive plant defense mechanisms, working in an orchestrated manner with a vast group of secreted defensive compounds such as the above mentioned vicilins, hydrolases and cystatins.

Acknowledgements: We acknowledge the financial support of the International Foundation of Science (IFS), Brazilian agencies CNPq and FAPERJ and of the Universidade Estadual do Norte Fluminense supporting body FENORTE. We thank Dr. Kátia V. S. Fernandes for critical review of this manuscript.

\section{REFERENCES}

Barbour WM, Hatterman DR, Scatey G (1991) Chemotaxis of Bradyrhizobium japonicum to soybean exudates. Appl Environ. Microbiol. 57: 2625-2639.

Bradford MM (1976) A rapid and sensitive method for the quantification of microgram quantities of protein utilizing the principle of dye binding. Anal. Biochem. 72: 248 - 254. 
Broekaert WF, Cammue BPA, De Bolle MFC, Thevissen K, De Samblanx G, Osborn RW (1997) Antimicrobial peptides from plants. Crit. Rev. Plant Sci. 16: 297-323.

Cammue BPA, De Bolle MGC, Terras FRG, Proost P, Damme JVan, Rees SB, Vanderleyden J, Broekaert WF (1992) Isolation and characterization of a novel class of plant antimicrobial peptides from Mirabilis jalapa L. seeds. J. Biol. Chem. 267: 2228-2233.

Cammue BPA, Thevissen K, Hendriks M, Eggermont K, Goderis I J, Proost P, Van Damme J, Osborn RW, Guerbette F, Kader J-C, Broekaert WF (1995) A potent antimicrobial protein from onion (Allium cepa L.) seeds showing sequence homology to plant lipid transfer proteins. Plant Physiol. 109: 445-455.

Carvalho AO, Tavares OLM., Santos IS, Cunha M, Gomes VM, (2001) Antimicrobial peptides and immunolocalization of a LTP in Vigna unguiculata seeds. Plant Physiol. Biochem. 39: 137-146.

Duvick JP, Rood T, Rao AG, Marshak DR (1992) Purification and characterization of a novel antimicrobial peptide from maize (Zea mays L. ) kernels. J. Biol. Chem. 267: 1881418820.

Gomes VM, Oliveira AEA, Xavier-Filho J, (1996) A chitinase and a $\beta$-1,3-glucanase isolated from the seeds of cowpea (Vigna unguiculata L. Walp) inhibit the growth of fungi and insect pests of the seed. J. Sci. Food Agric. 72:86-90.

Gomes VM, Mosqueda M-I, Blanco-Labra, A, Sales MP, Fernandes KVS, Cordeiro RA, Xavier-Filho J (1997) Vicilin storage proteins from Vigna ungiculata (Legume) seeds inhibit fungal growth. J. Agric. Food Chem. 45: 4110-4115.

Kader J -C (1996) Lipid-transfer protein in plants. Annu. Rev. Plant Physiol. Plant Mol. Biol. 47: 627-654.

Latunde-Dada AO (1990) Genetic manipulation of the cowpea (Vigna unguiculata [L.] Walp.) for enhanced resistance to fungal pathogens and insect pests. Adv. Agron. 44:133-154.

Macedo MLR, Fernandes KVS, Sales MP, Xavier-Filho J (1995) Purification and properties of storage proteins (vicilins) from cowpea (Vigna unguiculata) seeds which are susceptible and resistant to the bruchid beetle Callosobruchus maculatus. Braz. J Med. Biol. Res. 28:183-190.

Molina A, Segura A, Garcia-Olmedo F (1993) Lipid transfer proteins (nsLTP) from barley and maize leaves are potent inhibitors of bacterial and fungal plant pathogens, FEBS Lett. 2:119-122.
Nelson EB, Hsu JST (1994) Nutritional factors affecting responses of sporangia of Pythium ultimum to germination stimulants. Phytopathol. 84: 677 - 683.

Regente MC, De La Canal L (2000) Purification, characterization and antifungal properties of a lipid transfer protein from sunflower (Helianthus annuns) seeds. Physiol. Plantarum 110: 158-163.

Schagger H, Von Jagow G (1987) Tricine-sodium dodecylsulfate polyacrylamide gel electrophoresis for the separation of proteins in the range from 1 to $100 \mathrm{kDa}$. Anal. Biochem. 166: 368-379.

Segura A, Moreno M, Gracía-Olmedo F (1993) Purification and antipathogenic activity of lipid transfer proteins (LTPs) from the leaves of Arabidopsis and spicach. FEBS Lett. 332: 243-246.

Singh BB, Singh SR, Adjadi O (1985) Bruchid resistance in cowpea. Crop Sci. 25:736-739.

Singh SR, Rachie KO (1985) Cowpea, Research, Production and Utilization. 460 pp. John Wiley \& Sons, Chichester

Terras FRG, Schoofs HME, De Bolle MFC, Van Leuven F, Ress SB, Vanderleyden J, Cammue BPA., Broekaert WF (1992) Analysis of two novel classes of plant antifungal proteins from radish (Raphanus sativus L.) seeds. J. Biol. Chem. 267:15301-15309.

Terras FRG, Eggermont K, Kovaleva V, Raikhel NV, Osborn RW, Kester A, Rees SB, Torrekens S, Van Leuven F, Vanderleyden J, Cammue BPA, Broekaert WF (1995) Small cysteine-rich antifungal proteins from radish: their role in host defense. Plant Cell 7: 573 - 588.

Towbin H, Staehelin T, Gordon J. (1979) Electrophoretic transfer of protein from polyacrylamide gels to nitrocellulose sheets. Procedure and some applications. Proc. Natl. Acad. Sci. USA 76: 4350-4354.

Velazhahan R, Radhajeyalakshmi R, Thangavelu R, Muthukrishnan S (2001) An antifungal protein purified from pearl millet seeds shows sequence homology to lipid transfer proteins. Biol. Plant. 44: 417-421.

Xavier-Filho J, Campos FAP, Ary MB, Silva CP, Carvalho MMM, Macedo MLR, Lemos FJA, Grant G (1989) Poor correlation between the levels of proteinase inhibitors found in seeds of different cultivars of cowpea (Vigna unguiculata) and the resistance/susceptibility to predation by Callosobruchus maculates. J. Agric. Food Chem. 37: 1139-1143.

Xavier-Filho J (1993) Sementes e suas defesas contra insetos. Projeto Multinacional de Biotecnologia e Alimentos. Organização dos Estados Americanos (OEA), pp.1-31. 